\title{
KEINDAHAN DAN ORNAMENTASI DALAM PERSPEKTIF ARSITEKTUR ISLAM
}

Yulia Eka Putrie

Atik Hosiah
Jurusan Teknik Arsitektur, Fakultas Sains dan Teknologi, Universitas Islam Negeri (UIN) Maulana Malik Ibrahim Malang, Jawa Timur, Indonesia e-mail: ekaputrie.yulia@gmail.com

Jurusan Teknik Arsitektur, Fakultas Sains dan Teknologi, Universitas Islam Negeri (UIN) Maulana Malik Ibrahim Malang, Jawa Timur, Indonesia e-mail: tick_end87@yahoo.com

\begin{abstract}
This study discusses about the Islamic view from al-Quran and al-Hadith about beauty and its application in the form of architectural ornamentation of the building. This is done to obtain the basic philosophical as well as corridors for the implementation of the beauty in the building, as well as to restore the function of ornamentation itself. Of this study obtained an understanding that displayed beauty should still consider the values of Islam, namely the value of the benefit, harm avoidance, tauhid, cleanliness, and so forth. Between the harm to be avoided in the ornamentation of the mosque is a tendency to exaggerate (mubadzir), depiction of animate beings, disturbance of concentration, intention to brag, luxury, causing difficulty in maintaining cleanliness in the future, and so forth. The expression of beauty can also be done through simplicity, moderation, harmony with nature, concern for human needs and society, and conformity with the rules set by God Almighty and His Messenger.
\end{abstract}

Keywords: Ornamentation, mosque, islamic architecture, beauty

\begin{abstract}
Abstrak
Kajian ini membahas mengenai pandangan Islam berdasarkan al-Qur'an dan al-Hadits mengenai keindahan dan penerapannya di dalam arsitektur dalam bentuk ornamentasi bangunan. Hal ini dilakukan untuk memperoleh dasar filosofis sekaligus koridor bagi penerapan keindahan di dalam bangunan, serta untuk mengembalikan fungsi dari ornamentasi itu sendiri. Dari kajian ini diperoleh pemahaman bahwa keindahan yang ditampilkan sebaiknya tetap mempertimbangkan nilai-nilai Islam yang ada, yaitu nilai kemanfaatan, penghindaran kemudharatan, ketauhidan, kebersihan, dan sebagainya. Di antara kemudharatan yang harus dihindari dalam ornamentasi masjid adalah kecenderungan untuk berlebih-lebihan (mubadzir), penggambaran makhluk bernyawa, penyebab terganggunya konsentrasi, niat untuk menyombongkan diri, bermewah-mewahan, penyebab kesulitan dalam pemeliharaan kebersihan di masa mendatang, dan sebagainya. Ungkapan keindahan juga dapat dilakukan melalui kesederhanaan, tidak berlebih-lebihan, keselarasan dengan alam, kepedulian akan kebutuhan manusia dan masyarakat, dan kesesuaian dengan aturan-aturan yang telah ditetapkan Allah swt dan Rasul-Nya.
\end{abstract}

Kata kunci: Ornamentasi, masjid, keindahan, arsitektur Islam

\section{Pendahuluan}

Dr. Sidi Gazalba, di dalam bukunya "Mesjid Pusat Ibadat dan Kebudayaan Islam", menyatakan bahwa soal keindahan adalah soal kesenian. Seni adalah semua yang menimbulkan rencana keindahan atau keharuan dan semua yang diciptakan untuk melahirkan rencana itu. Rencana itu melahirkan kesenangan dan bertujuan kesenangan. ${ }^{1}$ Keindahan ini, menurut Gazalba, walaupun tidak identik, berhubungan mesra dengan kebaikan. Dalam hal ini, estetika berkaitan erat dengan etika; yang baik itu indah, yang indah itu baik. Aristoteles dalam bukunya "Rhetorica" merumuskan keindahan dengan kalimat, "that which being good is also pleasant", yaitu sesuatu yang selain baik juga menyenangkan. ${ }^{2}$ Jika ditelusuri dari asal kata 'beauty' dalam bahasa Latin, yaitu 'bonum' yang berarti kebaikan, maka tampaklah bahwa makna beauty (keindahan) berkaitan dengan pengertian kebaikan. ${ }^{3}$

Lebih jauh, dalam hubungannya dengan agama, akan nyata pula hubungan yang erat antara agama dengan seni, sebagaimana eratnya hubungan antara agama dan etika. Hal ini diperkuat dengan adanya sebuah teori ilmu kebudayaan yang berpendapat bahwa seni lahir dari agama. ${ }^{4} \mathrm{Di}$ dalam kebudayaan yang sederhana hingga yang tinggi tingkatnya, misalnya kebudayaan Bali, akan tampak bahwa seni berfungsi sebagai pernyataan agama. Ciptaan- 
ciptaan seni banyak yang lahir oleh rangsangan rasa agama, dan rasa agama yang menjelma menggerakkan rasa seni untuk mencipta. ${ }^{5}$

Keindahan memiliki arti khusus di dunia Islam. Dalam arsitektur yang berkembang di dunia Islam, nilai penting keindahan tampak mulai dari level filosofis hingga pada level operasional. Di dalam salah satu hadits dinyatakan bahwa Allah itu indah dan menyukai keindahan. Hadits ini banyak dijadikan dasar filosofis bagi pengembangan keindahan dalam arsitektur Islam.

Walaupun demikian, konsep keindahan dalam arsitektur ini bukanlah keindahan yang semata-mata berakhir pada penilaian akan bentuk yang kasat mata saja. Dalam bahasa Seyyed Hossein Nasr, terdapat pandangan-dunia (worldview) Islam yang mempengaruhi seni dan arsitektur islami secara umum. Karenanya, kelahiran citarasa artistik yang universal dalam arsitektur Islam dan bentuk-bentuk seni lainnya, dengan segala ide jeniusnya, perbedaan karakteristik dan homogenitas formalnya, menyangkut perbedaan budaya, geografis dan sifat temporal, tentu bukan lahir secara kebetulan belaka. ${ }^{6}$

Dari berbagai pendapat mengenai hubungan antara arsitektur Islam dengan keindahan, dapat ditarik benang merah bahwa filosofi dasar arsitektur dan seni yang dapat disarikan dari pandangan-dunia Islam adalah sebagai pengingat tauhid, keesaan dan kebesaran Allah swt. Pada dasarnya, filosofi dasar ini terkait erat dengan tujuan keberadaan manusia di dunia, yaitu beribadah kepada Allah. Pengertian ibadah sendiri di dalam Islam sangat luas, sehingga meliputi kegiatan berarsitektur yang didasarkan pada nilai-nilai Islam. Selain itu, mengingat Allah dalam setiap keadaan merupakan kewajiban setiap muslim dan merupakan salah satu kegiatan yang bernilai ibadah. Dalam kesehariannya berinteraksi dengan obyek arsitektur, maka peran arsitektur Islam menjadi sangat penting sebagai sarana pengingat tauhid bagi umat Islam itu sendiri.

Lebih jauh, Al-Faruqi menyatakan bahwa seluruh seni yang berkembang di dunia Islam memberikan bukti adanya penentuan oleh worldview Islam dan pandangan tauhid. Seluruh seni yang dikembangkan di bawah dorongan budaya Islam merupakan ungkapan Islam dan ideologinya. ${ }^{7}$ Demikian pula halnya dengan arsitektur yang diistilahkan Al-Faruqi sebagai "seni ruang". Arsitektur yang berkembang di dunia Islam juga merupakan ungkapan dari worldview Islam dan pandangan tauhid itu. Arsitektur Islam, walaupun tidak hadir dalam keseragaman bentuk yang kaku dan lebih merupakan penyesuaian dengan karakter arsitektur lokal di daerah yang dimasukinya, memiliki keterkaitan-keterkaitan yang menyediakan dasar bagi kesatuan estetis di dunia Islam, tanpa harus menekan atau melarang keragaman regional. ${ }^{8}$ Dipaparkan pula oleh S.H. Nasr, bahwa baik di Masjid
Delhi maupun Masjid Qarawiyyin, seseorang dapat merasakan kesamaan dalam seluruh bidang artistik dan spiritual, meskipun semua variasi lokal dalam hal materi dan teknik-teknik struktural tetap berbeda. ${ }^{9}$

Aliran seni Islam, menurut Gazalba, terletak di antara dua aliran seni lainnya, yaitu seni untuk seni (l'art pour l'art) dan seni untuk sesuatu. Aliran kedua menuduh aliran pertama sebagai aliran yang egois dan individualis. Sebaliknya, aliran pertama menuduh aliran kedua sebagai seni yang bertendensi, mengabdi kepada sesuatu yang di luar seni dan dengan demikian menempatkan diri lebih rendah daripadanya. Seni untuk seni dalam ciptaannya dikendalikan dari pangkalnya, sedangkan seni untuk sesuatu dikendalikan oleh ujungnya. Di dalam seni Islam, kesenian berpangkal dari takwa dan bergerak kepada satu tujuan, yaitu diri dan masyarakat. Laku perbuatan takwa ialah karena Tuhan, efeknya terjadi pada diri sendiri dan masyarakat. Dengan pengendalian pangkal cipta, tergaris sekalian tujuan. Maka seni islami menghimpun di dalam dirinya sintesa kedua aliran di atas. ${ }^{10}$ Kreativitas seni Islam adalah kebebasan yang bertanggung jawab, memperhatikan keindahan sekaligus kebenaran, sehingga produk seni Islam sarat dengan perpaduan estetika dan etika. ${ }^{11}$

Sejalan dengan pendapat-pendapat di atas, alFaruqi menyatakan bahwa selain sebagai ungkapan keindahan, seni dalam Islam juga merupakan ungkapan kebenaran dan kebaikan bagi para pemeluknya. $^{12}$ Pandangan tentang keindahan menurut al-Faruqi merupakan pandangan yang muncul dari pandangan dunia (worldview) tauhid yang merupakan inti ajaran Islam, yaitu keindahan yang dapat membawa kesadaran pengamat kepada ide transendensi. Seni Islam menurut al-Faruqi meliputi segala produk historis yang memiliki nilai estetis yang telah dihasilkan oleh orang-orang Muslim, dalam kurun sejarah Islam, berdasarkan pandangan estetika tauhid dan selaras dengan semangat keseluruhan peradaban Islam. Di dalamnya tercakup berbagai bidang seni, seperti seni sastra, kaligrafi, ornamentasi, seni ruang, dan seni suara. Seluruh seni ini berkembang berdasarkan enam ciri yang diambilkan dari al-Qur'an sebagai model ideal, yaitu abstraksi, struktur modular, kombinasi suksesif, repetisi, dinamisme dan kerumitan. ${ }^{13}$

\section{Ornamentasi dalam Arsitektur}

Di dalam arsitektur, ornamentasi merupakan hiasan yang digunakan dalam bangunan, usaha untuk menutupi atau menyamarkan bentuk asal dari suatu bahan atau struktur yang digunakan dalam bangunan. Ornamen adalah pola hias yang dibuat dengan digambar, dipahat, dan dicetak, untuk mendukung meningkatnya kualitas dan nilai pada 
suatu benda atau karya seni. Ornamen juga merupakan perihal yang akan menyertai bidang gambar (lukisan atau jenis karya lainnya) sebagai bagian dari struktur yang ada di dalam. ${ }^{14}$

Di dalam salah satu bukunya, al-Faruqi menceritakan seorang sejarawan seni Barat menjelaskan bahwa ornamentasi sebagai komponen hasil seni yang ditambahkan atau dimasukkan ke dalamnya, guna maksud-maksud hiasan. la juga menyebutkan bahwa ornamentasi adalah motif-motif dan tematema yang dipakai pada benda-benda seni, bangunan-bangunan atau permukaan apa saja tetapi tidak memiliki manfaat struktural dan guna pakai. Semuanya hanya dipakai untuk hiasan. ${ }^{15}$

Pengertian di atas merupakan salah satu sudut pandang yang memaknai ornamentasi dari segi manfaat struktur dan guna pakai saja, tanpa melihat fungsi ornamentasi dari segi makna dan pesan yang tersingkap di baliknya. Padahal, setiap ornamentasi mengandung makna dan pesan yang terungkap dalam berbagai corak hiasan. Oleh karena itu, ornamentasi memiliki bentuk yang beranekaragam berdasarkan rentang waktu dan wilayahnya. Akan sangat berbeda bentuk-bentuk ornamentasi dari China, Indonesia, Afrika, maupun Eropa. Di banyak tempat di dunia, ornamentasi juga muncul untuk mengungkapkan pesan-pesan religius. Keanekaragaman corak ornamentasi mengisyaratkan bahwasanya ornamentasi memiliki makna dari tiap bentuknya. Pada intinya, setiap ornamentasi memiliki makna dan ungkapan yang tersirat di dalamnya selain sebagai ekspresi keindahan. Bentuk-bentuk yang muncul pada ornamentasi yang beragam ini ternyata dapat mengidentifikasikan kebudayaan dan pandangan hidup dari suatu kaum. Ornamentasi merupakan salah satu bagian dari identitas suatu kebudayaan.

\section{Ornamentasi dalam Arsitektur Islam}

Al-Faruqi berpendapat bahwa ornamentasi bukanlah suatu hal yang "hanya ditambahkan secara superfisial" di dalam seni dan arsitektur Islam, melainkan sebagai suatu entitas yang menyatu dengan karakteristik seni Islam itu sendiri. ${ }^{16}$ Ornamentasi memainkan peranan yang penting dalam membentuk kesan ruang dan mempengaruhi persepsi pengamat. Di dalam seni Islam, menurut Isma'il Raji al-Faruqi ornamentasi mempunyai empat fungsi, yaitu (1) pengingat tauhid, (2) transfigurasi bahan, (3) transfigurasi struktur, dan (4) keindahan. ${ }^{17}$ Ornamentasi dalam Islam selain berfungsi sebagai keindahan merupakan penggambaran dari sebuah usaha untuk meningkatkan keimanan.

Menurut al-Faruqi, ornamentasi dalam Islam selain berfungsi sebagai keindahan, juga merupakan penggambaran dari sebuah usaha untuk meningkatkan keimanan, menyebabkan ornamentasi tidak hanya berfungsi sebagai pengisi ruang kosong dan keindahan saja. Ornamentasi juga merupakan upaya untuk membawa pemandangnya merasakan keberadaan dan kemahaindahan Tuhan dari pola dan corak yang ada. Hal ini diwujudkan dengan tidak ditonjolkannya karakteristik material, namun menyembunyikannya dalam ragam corak ornamen tersebut.

Pada masa pra-modern bangunan dengan ornamentasi banyak ditemui karena pada saat itu ornamentasi merupakan karakter dari kebudayaan yang mengandung pesan kepada dunia luar. Seperti pada masa peradaban Mesir Kuno, bangunan dengan bentuk ornamentasi yang bergambar, menceritakan kebudayaan mereka. Begitu pula pada masa peradaban Romawi dan Yunani.

Pada masa Arsitektur Modern, ornamentasi tidak digunakan lagi karena seiring dengan berjalannya waktu masyarakat tidak lagi memahami makna dari ornamentasi itu sendiri, dimana ornamentasi hanya digunakan sebagai hiasan tanpa mengerti makna. Arsitektur Modern mendasarkan diri pada fungsi, tiadanya ornamentasi, dan penghilangan unsur-unsur dekoratif yang tidak perlu.

Dalam perkembangan arsitektur di dunia Islam, ornamentasi juga digunakan sebagai wujud ekspresi keindahan. Akan tetapi ekspresi keindahan ini terkadang tidak diikuti dengan adanya pesan yang tersirat dan aturan yang tidak diperbolehkan dalam Islam, misalnya penggunaan kaligrafi ayat-ayat suci al-Qur'an sebagai ornamen yang diterapkan di lantai. Selain itu, adanya gambar-gambar makhluk hidup seperti manusia dan binatang yang digunakan sebagai elemen dekorasi bangunan. Adanya kenyataan bahwa ornamentasi sudah keluar dari koridor ini menandakan perlunya sebuah kajian mengenai dasar-dasar filosofis mengenai keindahan serta koridor-koridor dalam penerapannya di dalam karya arsitektur, salah satunya dalam ornamentasi bangunan. Maka penulisan ini dilakukan untuk menggali khasanah keilmuan Islam yang dapat dijadikan dasar filosofis bagi perwujudan keindahan di dalam arsitektur. Pada bagian berikut akan dibahas mengenai ornamentasi dalam hubungannya dengan arsitektur Islam sebagai koridor perancangan yang dapat menghasilkan suatu konsep ornamentasi yang islami.

Seperti telah dijelaskan sebelumnya, di dalam arsitektur Islam ornamentasi tidak terlepas dari unsur keindahan yang mempunyai makna yang baik dan berfungsi sebagai upaya meningkatkan keimanan. Dilihat dari fungsi ornamentasi itu sendiri salah satunya sebagai pengingat tauhid, dimana keindahan dapat membawa pengamat merasakan pengalaman ruang yang dapat mengingatkan akan keberadaan Tuhan lewat ciptaan-Nya, sehingga dapat meningkatkan keimanan.

Selanjutnya, dari sudut pandang nilai-nilai Islam, menciptakan sebuah keindahan bukanlah sesuatu yang dilarang, akan tetapi seorang peran- 
cang harus memperhatikan bagaimana keindahan itu sejalan dan selaras dengan nilai-nilai dan prinsip hidup Islam, dan bukannya merancang keindahan yang membawa mudharat bagi dunia dan akhiratnya. Keindahan yang sejalan dengan nilai-nilai Islam adalah keindahan yang tidak berlebih-lebihan, mengandung manfaat, tidak menimbulkan mudharat, sederhana, dan bukan merupakan ekspresi dari kesombongan. Keindahan yang demikian merupakan keindahan yang sesuai dengan prinsip dan nilai-nilai hidup Islam.

Dalam ornamentasi di seni dan arsitektur Islam, corak dan motif yang digunakan sebagian besar adalah corak-corak geometri, kaligrafi, dan corakcorak yang terinspirasi dari alam seperti stalaktit, sarang lebah, bunga, daun, dan sulur-sulur tanaman. Hal ini dikarenakan, pada dasarnya Islam melarang pemakaian hiasan dari bentuk-bentuk naturalistik dari manusia, binatang, atau mahluk hidup yang bernyawa. Seperti dalam hadits, Rasulullah saw bersabda "Sesungguhnya rumah yang di dalamnya terdapat gambar/lukisan (bernyawa) tidak akan di masuki oleh para malaikat" ${ }^{18}$. Dari hadits tersebut dijelaskan bahwa rumah atau bangunan lainnya yang di dalamnya terdapat gambar atau lukisan makhluk hidup bernyawa maka tidak akan dimasuki malaikat yang berarti jauh dari rahmat Allah. Inilah salah satu dasar yang dapat dijadikan hikmah dan acuan dalam mengekspresikan keindahan, sehingga tidak keluar dari koridor Islam.

Lebih jauh, keindahan yang sesuai dengan nilainilai Islam adalah keindahan yang tidak membawa kita pada kesombongan. Ibnu Mas'ud ra. meriwayatkan bahwa Rasulullah saw bersabda sebagai berikut:

"Tak akan masuk surga orang yang di dalam hatinya ada sebiji sawi dari kesombongan," ada seorang yang bertanya, "Sesungguhnya jika ada seseorang yang senang memakai baju baik dan sandal baik (apakah itu termasuk kesombongan?)", Nabi saw bersabda, "Sesungguhnya Allah itu indah, mencintai keindahan, kesombongan adalah menolak kebenaran dan membenci manusia". ${ }^{19}$

Dari hadits tersebut dapat dijelaskan bahwa keindahan tidak dilarang dalam Islam akan tetapi jangan sampai keindahan itu membawa kita pada keburukan dan hal yang dilarang dalam Islam. Keindahan yang tidak diniatkan untuk menyombongkan diri dan memamerkan benda-benda yang dimiliki tidaklah dilarang di dalam Islam. Untuk itu, hal yang perlu digarisbawahi adalah bahwa keindahan tidak selalu berhubungan dengan kemewahan dan kemegahan. Kemewahan dan kemegahan merupakan salah satu indikasi keinginan seseorang untuk menonjolkan diri di hadapan manusia lainnya dengan menunjukkan kelebihan dirinya. Sebaliknya, keindahan justru dapat diperoleh dari keselarasan dengan alam, kemanfaatan, dan kesederhanaan dalam bentuk. Hal ini dikarenakan, keindahan alam merupakan keindahan ciptaan Allah swt, dan selaras dengan alam merupakan salah satu cara untuk menghadirkan keindahan pula di dalam rancangan kita.

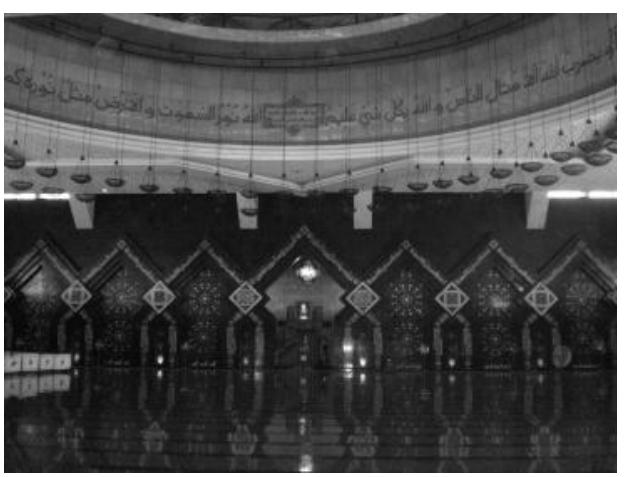

Gambar 1. Ornamentasi pada ruang shalat masjid (Sumber: Dokumentasi Pribadi, 2010)

Keindahan juga dapat membawa kita kepada kecenderungan untuk berlebih-lebihan, misalnya untuk mencapai keindahan penggunaan ragam hias atau ornamen diterapkan pada seluruh bagian bangunan, dimana tidak mempunyai fungsi lain, atau keberadaannya tidak memberi pengaruh. Ada atau tidaknya ornamentasi tersebut tidak mengurangi keindahan yang telah ada sebelumnya.

Untuk itu, perlu dipertimbangkan keberadaan ornamentasi sebagai wujud keindahan seni dalam arsitektur yang tidak hanya digunakan untuk mempercantik bangunan saja, akan tetapi juga memiliki manfaat lain, seperti pada Gambar 2 berikut ini. Ornamentasi pada dinding berfungsi pula sebagai elemen bukaan yang memasukkan cahaya dan aliran udara ke dalam ruangan.

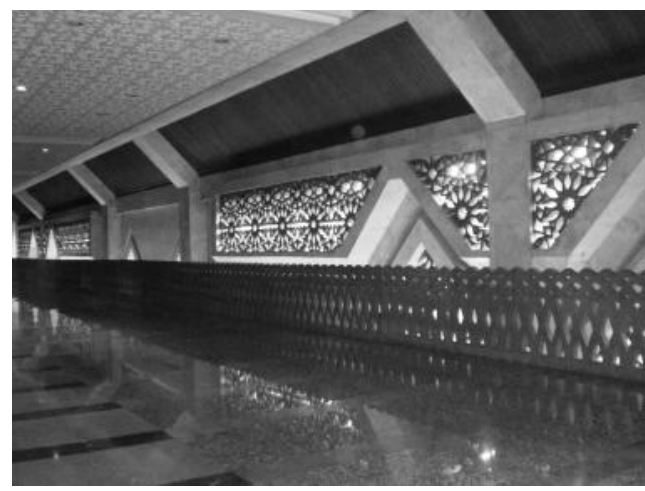

Gambar 2. Ornamentasi pada dinding masjid yang juga berfungsi memasukkan cahaya ke dalam ruangan (Sumber: Dokumentasi Pribadi, 2010)

Selanjutnya, keindahan yang mempunyai manfaat juga harus terlepas dari mudharat yang dapat ditimbulkan, karena lebih baik menghindari ke-mudharat-an daripada meraih satu manfaat namun menimbulkan mudharat bagi orang lain. Mudharat meliputi bahaya-bahaya yang menimpa 
fisik maupun yang menimpa agama, seperti menimbulkan kesyirikan, kesombongan, kemubadziran, tidak terjaganya privasi seseorang, dan sebagainya. Mudharat di dalam arsitektur dapat disebabkan kekeliruan atau kurangnya pertimbangan pada saat merancang suatu karya.

Spahic Omer di dalam salah satu bukunya, "The History and Character of the Islamic Built Environment", memaparkan bahwa Nabi Muhammad saw tidak hanya mengabaikan permasalahan dekorasi dan ornamentasi pada saat beliau membangun, namun beliau juga memberikan beberapa peringatan tentangnya di dalam beberapa hadits beliau. Salah satu dari hadits tersebut adalah yang menyatakan bahwa tidak ada yang lebih cepat memperburuk amal perbuatan seseorang daripada ketika mereka memulai menghias masjid-masjid mereka. ${ }^{20} \mathrm{Di}$ dalam hadits yang lain, Nabi Muhammad saw mengungkapkan bahwa salah satu dari tanda-tanda datangnya hari kiamat adalah ketika orang-orang mulai berlomba satu sama lain dalam menghias masjid. ${ }^{21}$ Beliau saw juga menyatakan bahwa ia tidak disuruh untuk mendirikan masjid-masjid yang monumental. Penulis dari hadits terakhir, Abdullah ibn 'Abbas, mengatakan, "Kamu pasti akan berakhir menghiasi masjid-masjidmu seperti orang Yahudi dan Kristen." 22

Pada hadits yang lain, Nabi Muhammad saw memerintahkan bahwa setiap kain atau tirai yang dihias dengan gambar-gambar untuk dihapus dari tempat yang digunakan untuk shalat agar tidak mengganggu kekhusyukan seseorang. Beliau bahkan melakukannya sendiri pada beberapa kesempatan. ${ }^{23}$ Pada hadits lain dinyatakan, setiap rumah harus bebas dari gambar-gambar yang mungkin bisa jadi mengganggu mereka yang shalat di sana. Diceritakan pula di dalam hadits lainnya, bahwa ketika Nabi Muhammad saw melihat sebuah kubah megah yang didirikan di atas sebuah rumah di Madinah, beliau saw berkata bahwa setiap kegiatan membangun bangunan adalah berbahaya bagi pemiliknya, kecuali dilakukan karena kebutuhan yang nyata. ${ }^{24}$ Karena itu, dapat disimpulkan bahwa sikap Islam terhadap hal-hal yang mubadzir telah jelas, termasuk dalam kegiatan membangun dan berarsitektur.

Namun demikian, ayat-ayat dan hadits-hadits tersebut tidak menyiratkan bahwa menghias bangunan itu dilarang sama sekali. Jika demikian halnya, baik al-Qur'an ataupun sunnah Nabi akan lebih spesifik dan eksplisit menyatakan setiap larangan (haram). Dari paparan di atas, dapat kita ambil pelajaran bahwa menghias bangunan yang dicela ialah yang berlebih-lebihan, menimbulkan bahaya (misalnya mengganggu konsentrasi ketika shalat), dan tidak memiliki manfaat yang jelas.

Dalam perkembangannya selama beratus-ratus tahun, ternyata tidak selamanya ornamentasi pada arsitektur masjid memiliki kesesuaian yang besar dengan nilai-nilai Islam. Pada sebagian besar masjid yang ada sekarang, keindahan justru menjadi faktor utama dibandingkan dengan faktor kemanfaatan masjid tersebut. Perkembangan arsitektur masjid saat ini tampak sebagai upaya untuk saling menonjolkan diri dan wilayah masing-masing dimana masjid itu dibangun. Hal ini terlihat dari ornamentasinya yang sangat masif dan terkadang menggunakan material-material yang mewah dan mahal seperti emas dan perak asli. Hal ini sangat bertolak belakang dengan nilai-nilai Islam yang telah dipaparkan di atas.

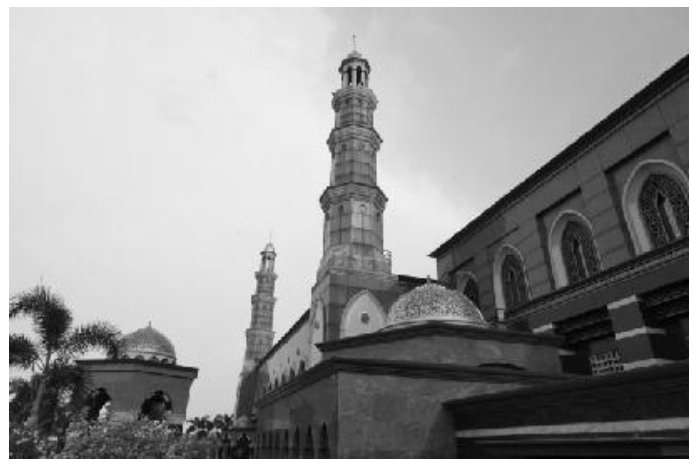

Gambar 3. Ornamentasi masjid dengan kubah dari bahan emas murni (Sumber: Dokumentasi Pribadi, 2010)

Ornamentasi sebagai bagian penghias dalam arsitektur masjid merupakan ungkapan rasa keindahan. Namun demikian, keindahan yang ditampilkan sebaiknya tetap mempertimbangkan nilai-nilai Islam yang ada, yaitu nilai kemanfaatan, penghindaran kemudharatan, ketauhidan, kebersihan, dan sebagainya. Di antara kemudharatan yang harus dihindari dalam ornamentasi masjid adalah kecenderungan untuk berlebih-lebihan (mubadzir), penggambaran makhluk bernyawa, penyebab terganggunya konsentrasi, niat untuk menyombongkan diri, bermewah-mewahan, penyebab kesulitan dalam pemeliharaan kebersihan di masa mendatang, dan sebagainya.

\section{Penutup}

Dari paparan di atas dapat ditarik simpulan bahwa ornamentasi sebagai ungkapan keindahan tidaklah dilarang di dalam Islam. Walaupun begitu, keindahan yang diawali niat baik itu tidak boleh menyebabkan seorang perancang melanggar batasbatas yang telah ditetapkan di dalam al-Qur'an dan al-Hadits, seperti larangan untuk bertindak berlebihlebihan, menunjukkan kesombongan, melakukan kerusakan di bumi, dan sebagainya. Keindahan yang dianjurkan di dalam Islam adalah keindahan yang bermanfaat dan tidak mengandung kemudharatan.

Lebih jauh, di dalam Islam keindahan di dunia tidaklah selalu identik dengan kemewahan atau keindahan yang dijanjikan Allah swt di dalam syurga- 
Nya. Keindahan di dalam Islam tidak dapat dilepaskan dari nilai-nilai kebenaran dan kebaikan yang ada di dalam Islam, tidak hanya dilihat dari bentuk fisik yang memukau, mewah, dan bagus semata. Hal yang secara fisik terlihat indah namun tidak baik dan benar, tidak akan indah pula pada akhirnya. Sebaliknya, hal yang secara fisik sederhana, namun mengandung kebenaran dan kebaikan akan terasa indah pula. Indah karena benar, indah karena baik. Karenanya, ungkapan keindahan juga dapat diwujudkan melalui kesederhanaan, tidak berlebih-lebihan, keselarasan dengan alam, kepedulian akan kebutuhan manusia dan masyarakat, dan kesesuaian dengan aturan-aturan yang ditetapkan Allah swt dan Rasul-Nya.

\section{Referensi}

1 Sidi Gazalba. 1975. Mesjid Pusat Ibadat dan Kebudayaan Islam. Jakarta: Pustaka Antara. hal. 206

2 The Liang Gie. 1996. Filsafat Keindahan. Yogyakarta: PUBIB. hal. 13

3 The Liang Gie. 1996. Filsafat Keindahan. Yogyakarta: PUBIB. hal. 17

4 Sidi Gazalba. 1975. Mesjid Pusat Ibadat dan Kebudayaan Islam. Jakarta: Pustaka Antara. hal. 206-207

5 Sidi Gazalba. 1975. Mesjid Pusat Ibadat dan Kebudayaan Islam. Jakarta: Pustaka Antara. hal. 208

6 Seyyed Hossein Nasr. 1993. Spiritualitas dan Seni Islam. Bandung: Penerbit Mizan. hal. 13-14

7 Ismail R. Al-Faruqi \& Lois Lamya Al-Faruqi. 2003. Atlas Budaya Islam, Menjelajah Khazanah Peradaban Gemilang. Bandung: Penerbit Mizan. hal. 442

8 Ismail R. Al-Faruqi. 1999. Seni Tauhid: Esensi dan Ekspresi Estetika Islam. Yogyakarta: Yayasan Bentang Budaya. hal. 5

9 Seyyed Hossein Nasr. 1993. Spiritualitas dan Seni Islam. Bandung: Penerbit Mizan. hal. 13

10 Sidi Gazalba. 1975. Mesjid Pusat Ibadat dan Kebudayaan Islam. Jakarta: Pustaka Antara. hal. 212-213
11 H. Gufron Hambali. 2006. "Cita Kesenian Islam (Tantangan ljtihad dalam Budaya)". Jurnal Religion and Science. Malang: Lembaga Kajian al-Qur'an dan Sains (LKQS) UIN Malang. hal. 281

12 Ismail R. Al-Faruqi \& Lois Lamya Al-Faruqi. 2003. Atlas Budaya Islam, Menjelajah Khazanah Peradaban Gemilang. Bandung: Penerbit Mizan. hal. 415

13 Ismail R. Al-Faruqi. 1999. Seni Tauhid: Esensi dan Ekspresi Estetika Islam. Yogyakarta: Yayasan Bentang Budaya. hal. vii-viii

14 W. Seriyoga Parta S.Sn \& Wayan Sudana M.Sn. 2003. Mengenal Ornamen. diakses dari http://yogaparta.wordpress.com pada tanggal 15 September 2010

15 Ismail Raji al-Faruqi. 1999. Seni Tauhid: Esensi dan Ekspresi Estetika Islam. Yogyakarta: Yayasan Bentang Budaya. hal. 124

16 (Al-Faruqi, 2003: 412).

17 Ismail R. Al-Faruqi \& Lois Lamya Al-Faruqi. 2003. Atlas Budaya Islam, Menjelajah Khazanah Peradaban Gemilang. Bandung: Penerbit Mizan. hal. 412

18 HR. Bukhari dan Muslim

19 HR. Muslim

20 HR. Ibnu Majah dalam Spahic Omer. 2009. The History and Character of the Islamic Built Environment. Selangor Darul Ehsan: Arah Publication. hal. 92

21 HR. al-Bukhari dalam Spahic Omer. 2009. The History and Character of the Islamic Built Environment. Selangor Darul Ehsan: Arah Publication. hal. 92

22 HR. Abu Dawud dalam Spahic Omer. 2009. The History and Character of the Islamic Built Environment. Selangor Darul Ehsan: Arah Publication. hal. 92

23 HR. Bukhari dalam Spahic Omer. 2009. The History and Character of the Islamic Built Environment. Selangor Darul Ehsan: Arah Publication. hal. 93

24 HR. Muslim dalam Spahic Omer. 2009. The History and Character of the Islamic Built Environment. Selangor Darul Ehsan: Arah Publication. hal. 93 